\title{
An analysis of the US discourse and EU policy towards the July 2013 military intervention in Egypt
}

\section{Mısır'daki Temmuz 2013 askeri müdahalesine yönelik Amerikan söylemi ve AB politikasının bir analizi}

Gönderim Tarihi / Received: 22.02.2021

Abdurrahman GÜMÜŞ ${ }^{1}$

Kabul Tarihi / Accepted: 29.09.2021

Doi: https://doi.org/10.31795/baunsobed.885063

\begin{abstract}
The Arab Uprisings in the regional sense came to a halt with the July 2013 military intervention in Egypt. The military intervention constituted a challenge for the global actors in terms of the level of their commitment to the principles and norms such as democracy and human rights. This article analyzes the US discourse towards the military intervention in Egypt by using the method of discourse analysis. Discourse analysis focuses on the reflexive relationship between discourse and context. Thus, the chaotic Egyptian context offers a good test for the US foreign policy. Furthermore, the EU policy during the Arab Uprisings will be addressed as a point of comparison for the US due to its normative character. Despite the support for democratic values and norms at the discursive level, the US foreign policy prioritized the longstanding alliance with Egypt and the Egyptian military based on shared interests. Naming the military intervention as a "coup" would lead to both political and legal consequences like cutting off the aid to the Egyptian military. In addition to the longstanding alliance, the legal consequences of a coup, possible effects of the US position on the European and regional actors as well as the need for keeping its reputation as a reliable ally contributed to cautious discourse and interest-based policy of the US. The US call for returning to a democratic order meant the acceptance of the results of the military intervention in Egypt and the maintenance of the discourse of "democracy promotion". On the other hand, the EU policies during the Arab Uprisings also reflected a gap between rhetoric and practice, and they ended in another missed opportunity for asserting its normative power. As a result, the military intervention in Egypt confirmed the primacy of interests rather than norms and principles for the Western actors.
\end{abstract}

Keywords: Discourse, Military intervention, Egypt, EU policy, Democracy

ÖZ: Arap İsyanları, Mısır’daki Temmuz 2013 askeri müdahalesiyle bölgesel anlamda durma noktasına geldi. Askeri müdahale küresel aktörler için de onların demokrasi ve insan hakları gibi prensiplere ve normlara bağlılık düzeyi açısından bir meydan okuma teşkil etti. Bu makale, söylem analizi yönetimini kullanarak Misır'daki askeri müdahaleye yönelik Amerikan söylemini analiz etmektedir. Söylem analizi, söylem ve bağlam arasındaki karşılıklı ve dönüşlü ilişkiye odaklanır, bu nedenle kaotik Mısır bağlamı, Amerikan dış politikası için iyi bir test niteliği taşımaktadır. Buna ek olarak, Arap İsyanları sürecindeki AB politikasından, AB'nin normatif karakteri nedeniyle ABD için bir karşılaştırma noktası olarak söz edilecektir. Söylem düzeyinde demokratik değerlere ve normlara verilen desteğe rağmen Amerikan dış politikası Mısır ve Mısır ordusuyla ortak çıkarlara dayalı uzun süreli ittifakı öncelemiştir. Askeri müdahalenin resmen "darbe" olarak isimlendirilmesinin siyasi sonuçlarının yanında Mısır ordusuna yapılan yardımın kesilmesi gibi hukuki sonuçları olacaktı. Uzun süreli ittifakın yanı sıra darbenin hukuki sonuçları, ABD'nin pozisyonunun Avrupalı ve bölgesel aktörler üzerindeki muhtemel etkileri ve ABD’nin güvenilir bir müttefik olma özelliğini koruma ihtiyacı gibi nedenler, ABD’yi temkinli bir söylem ve çıkar merkezli bir politikaya yöneltti. ABD'nin demokratik düzene dönülmesi yönündeki çağrısı, Mısır'daki askeri müdahalenin sonuçlarını kabul etmekle beraber demokrasi teşviki (promosyonu) söyleminin devam ettirileceği anlamına geliyordu. Diğer taraftan, Arap İsyanları sürecindeki AB politikaları da söylem ve eylem arasındaki bir boşluğu yansıtıyordu ve AB'nin normatif gücünü öne çıkarmasını sağlayacak bir başka firsatın daha kaçırılmasıyla sonuçlandı. Sonuç olarak, Mısır'daki askeri müdahale Batılı aktörlerin normlar ve prensipler yerine çıkarlarını öncelediğini doğrulamış oldu.

Anahtar Kelimeler: Söylem, Askeri müdahale, Mısır, AB politikası, Demokrasi

\footnotetext{
${ }^{1}$ Dr., Yıldız Teknik Üniversitesi/ İktisadi ve İdari Bilimler Fakültesi/ Siyaset Bilimi ve Uluslararası İlişkiler Bölümü/ Uluslararası İlişkiler Anabilim Dalı, abdurrahmangumus001@ @mail.com, https://orcid.org/0000-0002$\underline{1746-7876}$
} 


\section{GENIŞLETILMIŞ ÖZET}

\section{Literatür Taraması}

Arap İsyanları büyük ölçüde sosyoekonomik nedenler ve otoriter rejimlerden duyulan rahatsızlık gibi iç faktörlere bağlı olarak ortaya çıkmasına karşın sonraki süreçte dış aktörlerin de devreye girmesiyle birlikte isyanların patlak verdiği Ortadoğu ülkelerinde sürecin farklı yönlere doğru evrildiği bir durum ortaya çıktı. İlk anda isyanların ortaya çıkardığı kaotik atmosfere hazırlıksız yakalandığı gözlemlenen dış aktörler, politikalarını ve söylemlerini yeni konjonktüre uygun hale getirmeye çalışarak süreci kendi kontrollerine alma gayreti içine girdiler. Bu nedenle, Arap İsyanları bölgesel dinamiklerde önemli değişimlere yol açtığı gibi bölgeyle ve bölgedeki aktörlerle yakın ilişki içinde olan dış aktörlerin politikalarında ve ilişkilerinde de önemli dönüşümlere zemin hazırladı. Tunus’ta başlayan ve özellikle Mısır'da Mübarek'in görevi bırakmasıyla bölge geneline yayılan bu değişim ve dönüşüm dalgası, 2013 yılı temmuz ayında yine Mısır'da yaşanan askeri müdahale ile durma noktasına geldi ve bir anlamda karşı devrim çabalarıyla karşılaştı. Dış aktörler arasında hem küresel sistemdeki önemli konumları nedeniyle küresel aktör olarak nitelendirilen özellikleri hem de bölgeyle olan uzun süreli ve yakın ilişkileri nedeniyle ABD ve Avrupa Birliği öne çıkmaktadır.

$A B D$ ve $A B$ gibi küresel aktörlerin demokrasiyi teşvik etmeye yönelik söylemleri, askeri müdahalelere verdikleri tepkiler ve bu konulardaki söylemleri ile politikalarının uyumlu olup olmadığı sorusu çeşitli araştırmalara konu olmuştur. Literatürdeki çalışmalara baktığımızda ABD ve AB'nin normatif değerler ve özellikle demokrasinin yayılmasını teşvik etme konularında güçlü bir söylem üretmelerine rağmen uyguladıkları politikalar ve gösterdikleri performansın bu söylemi karşılamadığına dair olumsuz görüşlerin çoğunlukta olduğunu görüyoruz. Bu konuda yalnızca küresel aktörlerin suçlanamayacağı veya bu aktörlerin aslında böyle bir meselelerinin veya çabalarının olmadığını savunan daha farklı görüşler de mevcut olmakla birlikte en yaygın kanaatin eylem ve politikaların beklentileri ve söylemi karşılamadığı olduğunu ifade etmek mümkündür. İki aktör arasında kıyaslama yaptığımızda ABD’nin bir ulus-devlet olarak normatif yönünden ziyade çıkar odaklı dış politikasının öne çıktığını vurgulayabiliriz. Uzun süreli demokrasi teşviki politikalarına rağmen ABD'nin Ortadoğu'da otoriter rejimlerle güçlü bir işbirliğine sahip olması da bölgede demokrasiden çok istikrarı öncelediği görüşünü destekliyor. Diğer taraftan, AB'nin normatif yönü daha ağır basıyor ancak onun da siyasi ve ekonomik gücünü daha etkin ve belirleyici bir role dönüştürme konusundaki sorunları ve üye ülkeler arasındaki görüş farklılıkları onun daha pasif bir politika izlemesine ve Ortadoğu özelinde ABD'nin politikalarını takip etmesine yol açıyor. Sonuçta, literatürdeki çalışmaların genel olarak ABD ve $A B$ gibi küresel aktörlerin performanslarını eleştirdiği ifade edilebilir.

\section{Yöntem}

$\mathrm{Bu}$ makale, Mısır'da yaşanan askeri müdahaleye yönelik $\mathrm{ABD}$ söylemini liderler ve temsilciler düzeyinde incelemeyi amaçlamaktadır. Aynı zamanda AB'nin de askeri müdahaleye yönelik söylemi ve izlediği politikalar analiz edilerek bir karşılaştırma yapılacaktır. Bu anlamda demokrasi, insan hakları ve eşitlik gibi normatif değerleri güçlü bir söylem olarak ön planda tutan bu aktörlerin, Mısır'daki askeri müdahaleye vermiş oldukları tepkiler söylemlerini bu örnek olayda ne ölçüde sürdürebildikleri ve söylemleri ile eylemleri arasındaki tutarlılık derecesi değerlendirilecektir. Makalede vaka incelemesinin yanı sıra söylem üzerine odaklanmaya ve söylem ile bağlam arasındaki ilişkiyi ortaya koymaya en uygun yöntem olan söylem analizi yöntemi kullanılacaktır.

\section{Bulgular ve tartışma}

Arap İsyanlarının ortaya çıkması ve yayılması sürecinde dış aktörlerin rolü tartışılan konular arasında yer aldı. Dış aktörlerin önceki yıllarda bölgede izlemiş olduğu politikaların isyanları tetiklediğine yönelik görüşler söz konusu olsa da kitlesel hareketler ortaya çıktıktan sonraki süreçte dış aktörlerin daha çok ön plana çıktığını söyleyebiliriz. Bölgeyle olan yakın ilişkileri nedeniyle dış aktörler arasında $A B D$ ve $A B$ 'nin söylemleri ve politikaları bu dönemde daha çok öne çıkmıştır. $A B$ Dış İlişkiler Temsilcisi Catherine Ashton'ın hem isyanlar devam ederken hem de sonraki süreçte yaptığı açıklamalara baktığımızda AB'nin biraz çekimser kalmakla beraber demokrasiye hızlı bir geçişin sağlanması ve temel insan hakları ve özgürlüklerin korunması anlamında tutarlı mesajlar verdiğini görebiliriz. Ancak yapılan askeri müdahaleyi darbe olarak isimlendirmeme ve göreve gelen askeri 
yönetimin meşruiyetini tartışmaya açmama konusunda $\mathrm{ABD}$ ile benzer bir tutum takındıkları gözden kaçmamaktadır. $\mathrm{Bu}$ nedenle AB'nin söylem ve politikaları arasındaki farklılı̆̆a yönelik eleştirilerin Mısır'daki askeri müdahale örneğinde de benzer şekilde ortaya çıktığını ifade etmek mümkündür. Bu anlamda $\mathrm{AB}$, eleştirilere somut bir cevap verebilme ve etkin bir normatif ve küresel aktöre dönüşebilme fırsatını kaçırmış oldu.

ABD'nin Mısır' daki askeri müdahaleye vermiş olduğu tepkinin ise birkaç sebepten ötürü daha kritik bir önemi vardı. Öncelikle Mısır, uzun yıllardır ABD’nin Ortadoğu'ya yönelik dış politikasında stratejik öneme sahip bir aktördü. Aynı şekilde Mısır ordusu ile ABD arasında güçlü ilişkiler söz konusuydu. Her ne kadar ABD ile Müslüman Kardeşler arasındaki ilişkiler yakın olmasa da bu durum, ABD'nin askeri müdahaleye tepki göstermemesi için tek başına yeterli bir sebep değildi. İkinci olarak, ABD'nin Mısır'daki askeri müdahaleyi darbe olarak isimlendirmesinin hukuki sonuçları olacaktı. ABD'deki federal yasalara göre güç kullanımı ve darbe yoluyla yönetimin değiștiği ülkelere ABD'nin yapmış olduğu yardımı kesmesi gerekiyordu. ABD'nin finansal ve lojistik yardımı ise Mısır ordusu için hayati bir öneme sahipti. Ayrıca ABD'nin söylemi ve vereceği tepki, AB ve diğer aktörler üzerinde de önemli bir etkiye sahip olacaktı. Bu sebepler, ABD'nin Mısır'daki askeri müdahaleye yönelik ihtiyatlı bir söylem geliştirmesi sonucunu doğurdu. Dönemin Amerikan Başkanı Obama ve Amerikan yönetimi sözcülerinin açıklamaları, kitlesel gösterilere katılan Mısır vatandaşlarının taleplerinin meşru olduğunu dile getiriyordu. Obama, Mübarek karşıtı gösteriler sırasında da Mübarek'in görevi bırakması gerektiğini ilk dile getiren liderlerden biriydi. Askeri müdahale sırasında taraflara sükûnet çağrısı gibi daha tarafsız görünen söylemler söz konusuydu. Ancak ABD gibi önemli bir gücü ve etkisi olan küresel aktörün tarafsız kalmasının da anlamları ve sonuçları olduğunu kabul etmek gerekir. Obama'nın açıklamalarında dile getirdiği demokratik düzene hızlı bir geçişin sağlanması, kapsayıcı bir yönetimin oluşturulması ve temel hak ve özgürlüklerin korunması gibi söylemlerin sözü edilen değerlerin Amerikan dış politikasındaki yerini vurgulamakla beraber oluşan yeni durumun yani askeri müdahaleyle yönetimin el değiştirmesinin kabullenildiğini gösterdiği sonucunu çıkarabiliriz. Obama ve diğer ABD temsilcileri hukuki sonuçları da olan darbe isimlendirmesinden özellikle kaçındığını görebiliyoruz. Kapsayıcı hükümete yönelik vurgunun da Mursi döneminde Misır'daki yönetimde bunun başarılamadığına yönelik eleştirileri içerdiği şeklinde okunabilir. Mısır ordusunun ABD ile olan yakın ilişkileri ve ABD yardımı ve desteğine önemli ölçüde bağımlı olduğunu hesaba kattığımızda bu askeri müdahalenin ABD'nin açık veya örtülü bir desteği olmadan gerçekleştiğini düşünmek zordur. Sonuç olarak, ABD'nin Mısır'daki askeri müdahaleye karşı vermiş olduğu tepkinin darbe karşıtı ve demokrasi yanlısı ilkesel bir tepkiden ziyade ABD'nin bölgeye yönelik çıkarlarını önceleyen bir söylem ve politikayı yansıttığını ifade edebiliriz. Bu da ABD'nin bölgedeki çıkarlarını ve istikrarı ön plana alan dış politikasıyla örtüşmektedir.

\section{Sonuç ve öneriler}

Arap İsyanları dış aktörlerin söylem ve politikaları açısından da önemli bir test ve meydan okuma olarak ortaya çıktı. Bölgede otoriter rejimlerin uzun süreli yönetimleri nedeniyle devam eden otoriter istikrar süreci, bölge genelindeki isyanlarla birlikte yerini önemli bir değişim ve dönüşüme bırakmıştı. Mısır'daki askeri müdahale ise bu değişim dalgasının durmasına ve tersine dönmesine yol açtı. Normatif değerleri ön plana çıkaran $\mathrm{AB}$, yine benzer söylemleri dile getirmekle birlikte bu süreçte aktif bir rol oynayamadı. ABD ise izlediği politika ile demokrasiden ziyade çıkarlarını ve istikrarı öncelediğini göstermiş oldu. Sonuçta $\mathrm{ABD}$ ve $\mathrm{AB}$ gibi küresel aktörlerin Mısır'daki askeri müdahaleye vermiş oldukları tepkilerle bu testte başarılı olduklarını söyleyemeyiz. Üretmiş oldukları söylemi Arap İsyanları bağlamında değerlendirdiğimizde beklentiler ve performans arasında yine ciddi farklılıklar ortaya çıktı. Bu durum bölgede oluşan siyasi değişim beklentileri ve bölge halklarının dış aktörlerden bekledikleri desteği alamamaları anlamında bir hayal kırıklığıyla sonuçlanmış oldu. ABD ve AB'nin Mısır'da yaşanan darbe sürecine yönelik söylemlerine ve politikalarına odaklanan bu çalışma, özellikle farklı normatif değerleri ön plana çıkaran aktörlerin söylem ve eylemleri arasındaki ilişki açısından bir örnek çalışma niteliği taşımaktadır. Söylem analizi yöntemi kullanılarak farklı aktörler ve örnek olaylar üzerine yapılacak çalışmalar, bu konudaki literatürü daha zengin hale getirecektir. 


\section{Introduction}

The role of external actors in the military interventions has long been debated by the scholars. Furthermore, the attitudes or reactions of great powers towards the military interventions in other countries may become decisive according to the domestic context and the special relationship of the external actors with the domestic ones. Since some of the great powers have normative elements in their official discourses such as human rights and promoting democracy, their policies towards the countries which experienced military interventions attract more attention. In other words, it is expected to see consistency between discourses and policies especially for democracy-promoting states during the coup attempts. However, in most cases, the normative elements do not become so decisive for these great powers. On the contrary, they prefer to pursue their strategic interests and the conditions of Realpolitik rather than their ideals and norms. This situation certainly creates a dilemma for hegemonic powers but expanding power and achieving their strategic interests constitute the main dynamic in their foreign policy. In that regard, our broader question can be formulated as how and why great (or hegemonic) powers implicitly or explicitly give support to military interventions or cooperate with authoritarian regimes despite the normative or ideal elements in their foreign policy rhetoric such as human rights and democracy promotion. Because the US has been the most powerful state in the world for a long time and the EU has always put emphasis on normative elements in their decisions, their relations with the authoritarian regimes and their reactions and roles towards the military interventions come into prominence. Traditionally, they continued to use these normative aspects in their official foreign policy discourses and put into practice some projects under the framework of human rights and democracy promotion. In spite of this, historical records show that they preferred to establish good relations with the authoritarian regimes for maintaining stability especially in the Middle East for decades and their strategic interests and calculations outweighed their normative concerns during the coup attempts. This situation made their rhetoric problematic in terms of normative aspects but they did not avoid sacrificing them for keeping their power and interests against challenges. The emergence of the Arab Uprisings created hope for democratization in the Middle East and it challenged the traditional policies of the great powers in the region. Put differently, it led to a new test for the US and EU discourse based on democracy promotion but they had mixed records in different cases and could not perform well again. The last military intervention in Egypt indicated the gap between rhetoric and policies for these actors.

Egypt experienced a military intervention in July 2013 after the protests started at the first anniversary of Morsi Presidency. It was of critical importance not only for Egypt but also for the regional balance of power especially in the dynamic atmosphere of the Arab Uprisings. In other words, overthrow of Morsi had different meanings for all the regional and global actors in that context. Among them, the position and attitude of the US towards the military intervention was more significant compared to other actors. First of all, Egypt has long been one of the main allies of the US in the Middle East. Despite the fact that the US had problematic relations with the Muslim Brotherhood, it was not a sufficient reason for suspending all the relations with Egypt due to its central place in the regional political affairs. Secondly, the decision or definition of the US about the military intervention would have legal consequences for the US aid to the Egyptian military. According to federal law, U.S. aid must be cut off to the countries where the elected government is overthrown by a military coup (Miller, 2013). Last but not least, the US policy towards Egypt would have an influence on the policies of other external actors especially the European powers. As a result of these conditions, President Obama and spokespersons of the Obama administration preferred to use cautious expressions not to remain in a difficult or binding situation for the US. They deliberately avoid calling the event as a coup d'état because of its legal consequences for the US aid. The US aid was vital for the Egyptian military and it was decisive for the Egypt-US relations. On the normative aspect, democracy promotion had been an important tool for the US discourse. Therefore, the military intervention in Egypt created a dilemma for the Obama administration. In this article, I will focus on the US discourse towards the events happened in Egypt during and after the military intervention in July 2013. The data coming out of the expressions of the President Obama and spokespersons of his administration will be used and those expressions will be analyzed by focusing on the language they used and putting them into the features of Egyptian context through the method of discourse analysis. This research will enable us to gain insights about the diplomatic language that was used by the representatives of the US Presidency. Furthermore, this case will be helpful to see the dynamic relationship between language and context. Our main research 
question can be formulated as such: What were the main elements of the US discourse towards the July 2013 military intervention in Egypt and why did the Obama Presidency prefer that discourse instead of calling the event as a coup? After that, the EU policy and discourse towards the military intervention will be addressed as a point of comparison.

In the next part, I will briefly focus on the method of discourse analysis which will be used in the main part of the article. It will be helpful for understanding the basic features of this particular method. After that, I will present the literature review on the democracy promotion rhetoric and policies of the EU and the US towards different cases. Although my major focus will be on the US discourse on the last military intervention in Egypt, this literature about the great powers will provide a framework and theoretical background in order to put the specific case into practice. Otherwise, this case will not be so meaningful or sufficient in terms of explanatory power. Then, I will go over the roles of external actors in the Arab Uprisings through which the details of the context will be highlighted. This context provides information about the influence of the external powers, especially the US and the EU, on the emergence and evolution of different cases of the Arab Uprisings. It can be regarded as a point of reference for comparing the Egyptian experience with other cases. Having explained the roles of external powers in general, I will concentrate on primarily the foreign policy of the EU towards the Arab Uprisings and subsequently, the US discourse on the military intervention in Egypt. Therefore, my approach can be summarized as step-by-step and from general to specific. It will, hopefully, ease analyzing the main case in the end.

\section{Literature review}

In the literature, there are some studies and arguments of scholars towards democracy promotion rhetoric and the policies of the EU and the US towards different cases. Although some positive attitudes or evaluations exist among them, most scholars emphasize the gap between rhetoric and policies for these actors. The Arab Uprisings and the policies of the US and the European actors towards different cases of this unexpected phenomenon are taken into account as a new focus.

Starting with some positive evaluations for the US foreign policy, Kenneth Wollack puts forward the idea that "the question of being US foreign policy on either values or interests has become a false dichotomy" (Wollack, 2010: 20-25). A number of such scholars aim to reach a balance between theory and practice in the foreign policy of external powers. Henry Nau gives some policy recommendations for the Obama administration about promoting democracy and to stop pendulum swing from force to diplomacy in an early period (Nau, 2010: 27-47). Perez de las Heras (2015) underlines the necessity of more dialogue and a joint strategy together with common institutions under the framework of Transatlantic Partnership for human rights and democracy promotion by the US and the EU. Despite some examples of positive evaluations, most studies in the literature criticize foreign policy of the US and the EU depending on some concrete results.

It is possible to present some ideas even questioning the existence of normative or ideal elements in the foreign policy discourse. Cox argues that "democracy was never a major US foreign policy aim" (Cox, 2013: 36-39). He points out expanding power, promoting economic interests, maintaining stability and balance of power as the foreign policy preferences of the US. Mohamed Metawe mentions an implicit agreement between the West and the dictatorship regimes in the Arab world (Metawe, 2013: 141). For him, the West was pragmatic in its reaction and Western powers support democracy only when it serves their interests. Despite changing context with the Arab Uprisings, Metawe considers a possibility for keeping the implicit agreement in a different way. Kivimaki (2013) also puts emphasis on the primacy of economic and strategic security interests for the US foreign policy towards the Middle East.

On the other hand, there are some studies in the literature showing the gap between the democracy promotion discourse and actual practices in different cases. Edmund Ratka shows the absence of a common agenda among European actors (Ratka, 2012: 65). Karakir (2014) underlines the inconsistency between EU as a moral power and its actual policies and she argues that the Arab Uprisings indicated the failure of the EU policies towards the Middle East. The EU could not decide how to respond towards the Arab Uprisings and play a decisive and outspoken role in that regard. In terms of the US foreign 
policy, some scholars pay attention to the fact that the changes in the Middle East especially after the Arab Uprisings uncovered the flaws of the US foreign policy so there is a need for reformulation of conventional policies in that sense (Pinto, 2012; Monshipouri \& Assareh, 2011: 121). Apart from that, Mohammed Nuruzzaman (2015) compares the early Obama period and his legacy during the Arab Uprisings (171-190). Despite the discourse on a "new beginning" with the Middle East, President Obama's foreign policy created dilemmas and left mixed records in the region (obamawhitehouse.archives.gov, 12.03.2019). Therefore, there was an obvious gap between rhetoric and practice in the Middle Eastern cases.

In short, the roles of EU and the US as normative powers promoting democracy and human rights are highly problematic depending on the policies of these actors especially during the cases where these normative or ideal elements clash with the strategic interests of these actors. The emergence of the Arab Uprisings was another test for them in terms of their approach to democratization and questioning their conventional policies towards maintaining stability but they could not get better results in different cases. Instead, they left mixed and incoherent legacies in those cases. Thus, it increased criticisms towards the normative aspects and roles of these actors.

\section{Methodology}

In this part of the article, I will explain the features of the discourse analysis. The idea of discourse is based on the constructivist view that is formulated as "everything is socially constructed" so everything can be a matter or object of discourse. There is a reflexive relationship between discourse and context. Put differently, while discourse shapes its context, it is also shaped by its context as well. The same kind of reflexive relationship can also be observed between discourse and the object it had an influence on. It means that the objects of discourse affect or shape discourse itself. This reciprocal or reflexive relationship can also be observed in the role and mechanism of language in daily lives. Language is used to express opinions and feelings and it becomes the basic means of communication. On the other hand, language evolves through time under the influence of people using language and some external factors. Thus, language is generally considered as a living being due to its evolution or transformation and the changes in language can be seen from generation to generation. Discourses, which are based on meaning systems, play a certain role here because they shape language purposefully and have a direct influence on language besides the natural evolution of language itself. Furthermore, there are relations among different discourses in successive periods. A particular discourse is shaped by the prior discourse and it shapes the next one. As a result, there is a special reflexive or reciprocal relationship between discourse and the world around it.

Before explaining the definition and characteristics of discourse analysis, it will be better to put forward what discourse analysis is not or what it rejects. First of all, discourse analysis is based on the idea of language as an action so according to it, theory cannot be separated from the reality it seeks to explain. Furthermore, discourse analysis rejects the search for scientific laws of society and politics because it supports the idea that everything is socially constructed. Apart from that, discourse analysts are located in a particular context and they refrain from the rigid separation of facts and values. I will focus on the relationship between discourse and context in the next parts. In terms of scientific approach, discourse analysis rejects crude empiricist and positivist approaches as well as essentialist and reductionist theories. Therefore, it excludes simplistic behavioral, rationalist and positivist approaches. Socially constructed meanings and interpretations are not crudely separated by discourse theorists as well. These rejections or challenges give us clues about the boundaries or framework of discourse analysis. As a result, they will be helpful for determining the exact place and definition of discourse analysis.

Having presented the main definitions or features of discourse and excluded parts of discourse analysis, it is now possible to argue the definition and content of discourse analysis. Discourse analysis, as a method, is based on the idea of examining language in relation with its context. It takes part among the qualitative research methods and provides a good understanding of the impact of context like other qualitative methods (Garcia \& Gluesing, 2013: 426). Therefore, it is necessary to evaluate the features of context and language through which they were used in order to see the relationship between them. As a qualitative research method, discourse analysis has resemblance to other "broadly qualitative, 
interpretive research methods" but there are certain criteria to put it into practice (Bax, 2011: 96). Discourse analysis can be used in combination with other research methods and it may increase the effectiveness of research studies in that way. Since "language is seen as an action" by discourse analysts, I attribute very much importance to the language in this research (Wood \& Kroger, 2000). Because of the inherent nature of discourse analysis as a method, this study focuses on the mutual relationship between language and "the situation networks" at a particular time and place (Gee, 1999: 92). As I have also underlined in the first part, there is a reciprocal or reflexive relationship between discourse and its context because discourse and its context affect each other (Johnstone, 2002). Texts are considered as written languages, and a discourse analysis includes both written and spoken materials. I have chosen using discourse analysis to the general picture because this method goes beyond the content or the material itself, and it requires an analysis of language and the factors which may impact it together with the context in which it emerges. Therefore, it is possible to make a comprehensive research and reach useful and reliable conclusions with this method.

\section{Findings and discussion \\ The role of external actors in the Arab Uprisings}

The Arab Uprisings emerged as a result of domestic reasons such as socioeconomic problems and political demands towards changing long-term authoritarian regimes of the Middle Eastern countries. These domestic factors led to mass demonstrations with the participation of different segments of the Arab societies. In the following period, the external actors began to involve in the process and they adopted different positions in accordance with their policies towards the region and their relations with the regional actors. Because of the central place and power of the global actors in international relations, the US and the European actors began to play more prominent and decisive roles in that period. The Arab Uprisings evolved into diverging paths in different countries and the role of external actors differed from case to case. As a result, the Arab Uprisings cannot be understood without analyzing the role of external actors for each case. There were even some claims attributing a role to the activities of the Western actors in the emergence of the uprisings. For Tariq Ramadan, "to suggest that these events came from nowhere is naïve" so he proposes a middle path between "the idea of completely internally driven movements and the conspiracy theories" (Ramadan, 2012: 9). He addresses the education of the bloggers and some members of leading groups like April $6^{\text {th }}$ movement about non-violent mobilization and their impacts on the social mobilization by the Western experts. Therefore, the role of external factors in both the emergence and evolution of the movements should be kept in mind. It was also claimed that the Arab Uprisings came out of domestic reasons and they were relatively peaceful in the initial period but the following period in which foreign actors involved turned nasty (Ghilés, 2012: 15). The role of external actors in the later period was more decisive.

Among the external actors, the US and the European actors come into prominence due to their special relations with the regional actors and former policies towards the region. Russia, China, and some nonArab regional actors such as Turkey and Iran can be regarded as other influential players for the Middle East. Since the Western actors had strong discourse based on some norms and principles such as human rights, democracy, and rule of law, the protestors expected strong support on behalf of themselves against the authoritarian regimes. However, the policies of the Western actors could not meet their demands; on the contrary, they created disappointment in the Arab societies. The US and the European actors preferred tactical policies and Realpolitik calculations such as "case-by-case approach" and "wait-and-see approach" instead of a moral or principle-based foreign policy (Metawe, 2013: 143). This policy reflected the general criticism towards the US foreign policy prioritizing the security of Israel, oil resources and terrorism in the Middle Eastern affairs (Turner, 2012: 177). In the context of the Arab Uprisings, the US foreign policy towards the Middle East did not make a radical shift in that sense. Thus, preference of the US decision-makers in favor of geopolitical and strategic interests rather than normative values and principles constituted the main point of debates. Moreover, the US was also criticized because of its policy and rhetoric against the undemocratic practices especially in the Morsi period in Egypt. It was claimed that foreign aid was a useful leverage or tool for the Obama administration as a way of conditionality but they intentionally refrained from using it (Collins \& Rothe, 2012: 18; Pierce, 2014). The US foreign policy in the Obama period was described as "weak, reluctant and too disengaged with the region" during the Arab Uprisings (Cole, 2013: 8-9; Sharp, 2014: 68). 
Consequently, the policies of the US and European actors reflected continuity in terms of their foreign policies towards the region and they were far from meeting the demands and expectations of the Arab people.

\section{The discourse and foreign policy of the EU towards the Arab Uprisings}

The Arab Uprisings erupted as a great challenge not only for the EU but also for all actors getting involved in the regional affairs in the Middle East so the EU and the European states were undoubtedly caught unprepared in the beginning. Before going the details about the analyses of the scholars about the EU's foreign policy, the traditional interests and priorities of the EU in the Middle East will be pointed out. Preservation of regional stability was considered as the essential point for the European actors in order to protect "the major priorities of the EU, including containments of migration, energy security, bilateral trade and economic relations, as well as security/ counterterrorism fears" (Karacasulu \& Karakir, 2014: 209). Stability has been the key word for all the external actors, including the US and the EU, in the region. They established good relations with the authoritarian rulers and they aimed to get more benefits by preservation of the existing regimes there. Therefore, the challenge of the Arab Uprisings against this regional order created shock for the external actors. While they were cautious in the beginning, they tried to readjust their foreign policies according to the changes on the ground. "The Uprisings induced a radical change of the choices in matter of EU foreign policy" in that sense (Rouet, 2014: 9). It should be underlined that the Arab Uprisings cannot be seen as an undivided whole so the responses of an actor, the EU in this article, should be analyzed case-by-case before reaching more general conclusions.

The Arab Uprisings started with the self-destruction of Mohammed Bouazizi in Tunisia and spread to the other countries in the region. The EU could not show strong reactions due to some reasons and preferred to adopt a wait-and-see approach. This approach was interpreted as the indicator of "European reluctance and indecisiveness about which side to support" (Wouters \& Duquet, 2013: 238). The initial reaction was generally explained by lack of a coherent policy and common understanding among the EU member states and the later developments and contradicting policies among them strengthened this view. After the initial shock was overcome, the EU and European powers tried to determine their policies carefully but more confidently compared to the first period. In the period in which the Tunisian President Ben Ali left the country and a transitional government was established while the mass demonstrations and protests were continuing in Egypt, EU High Representative for Foreign Affairs and Security Policy Catherine Ashton expressed the EU's welcome for the protests reflecting "legitimate grievances and aspirations as well as demands for change" and she called for meeting the demands of people and transition to democracy in both Tunisia and Egypt (ec.europa.eu/commission, 02.02.2011). This expression certainly reflected the traditional EU discourse and it included the EU norms and principles but they had to be completed with concrete proposals and policies on the ground. Since the long rule of the authoritarian leaders came to an end in a short period in Tunisia and Egypt, the European actors preferred to choose their side with the protestors instead of defending the authoritarian leaders. It was obviously pragmatic and tactical way of dealing with the crisis. The EU also declared some proposals such as "a partnership for democracy and shared prosperity with the Southern Mediterranean" in 8 March 2011 and another joint communication formulated as "a new response to a changing Neighborhood" (ec.europa.eu/commission, 16.12.2011). These initiatives aimed to combat with two main challenges, namely building "deep democracy" and "ensuring inclusive and sustainable economic growth and development", by providing some facilities such as money, mobility and market for each country in the region. Against the ouster of Morsi as a result of military intervention, Catherine Ashton condemned the violence and urged "all sides to return to the democratic process and an inclusive new administration" (dw.com/en, 21.02.2019). Obviously, this expression reflected a cautious attitude rather than rejection of military intervention and unconditional support for democracy in principle. The EU and the leaders of the European states followed the US through their expressions in that sense. Consequently, there is consistency in the EU discourse in terms of emphasizing the EU norms and principles but the EU's hesitance at the critical moments and lack of supporting effective policies lead to criticisms about the sincerity of the EU as a normative power due to the primacy of actions over discourses. 
The Arab Uprisings emerged as a great challenge for the EU and each case was a critical test for the performance and practices of the EU. However, the EU's reactions against the Uprisings were unsatisfactory in general, and disappointing in some cases. Schumacher summarizes the role of EU in the Middle East: "The EU continues to be torn between being a relevant political actor in the MENA region and a simple spectator" (Schumacher, 2011: 108). Moreover, the author underlines the importance of "the imbalance between divergence and convergence of interest" as the key impediment to greater EU actor capability. Apart from that, the normative aspect of the EU policies has lost its popularity because of its secondary importance against the interests of the EU and European states. This perception was strengthened during the whole process of the Arab Uprisings: "The ethical dimension of EU foreign policy is functional only when it does not contradict with its stability-related interests" (Karakir, 2014: 56). In other words, the victory of power politics over the normative dynamics has been accepted after several tests. The Arab Uprisings ended in failure for the normative dimension of the EU. There were some humanitarian policies and practices during the process and they were exceptional cases over which the European states could create a common policy but they were not sufficient for being an effective normative power. In the literature, there are also some ideas claiming that the EU assumes an active role in the MENA. However, the policies of the EU and its lower status compared to other actors during the Arab Uprisings will most probably increase negative comments and views towards the EU in the long-run so the EU has to make radical changes in order to get more credibility in the eyes of the local people and scholars as well.

\section{US discourse towards the 2013 military intervention in Egypt}

In the initial period of the Arab Uprisings, Obama expressed his welcome for the struggle of the Tunisian people and their determination for change in the date when the Tunisian President Ben Ali left the country as a result of mass protests (obamawhitehouse.archives.gov, 14.01.2011). During the protests against the Mubarak regime in Egypt, the Obama administration repeatedly addressed the legitimate grievances and demands of the Egyptian people. Obama reminded the responsibility of the Egyptian government for "putting forward a credible, concrete and unequivocal path toward genuine democracy" just before Mobarak's resignation (obamawhitehouse.archives.gov, 10.02.2011). After that, Obama called Mobarak's decision to step down as a historic moment and "a response to the Egyptian people's hunger for change" and he expressed the continuation of partnership between the US and Egypt (obamawhitehouse.archives.gov, 11.02.2011). These official expressions can be interpreted as the US welcome for the aspirations of the protestors. The strong demand for change in the Arab societies and mass demonstrations urged all the actors to adjust their policies and discourses towards the region. When the popular protests against Morsi Presidency gained a momentum after the involvement of Egyptian military and ended in a military intervention, it was important to see the policies or early remarks of the US representatives in order to understand their position. The basic question was about whether they would refer to the democratic principles and explicitly reject the military intervention by calling it as a "coup" or they would adjust the situation by accepting the de facto control of the military. In the official declaration of the US Presidency, Barack Obama expressed the official position of the US and underlined some important issues such as the US commitment to some crucial principles including "opposition to violence, protection of human rights and democratic process", the importance of the demands and grievances of the Egyptians, close monitoring of the process in Egypt by the US, its expectation to return authority to democratically elected civilians and to avoid arbitrary arrests, the need for a democratic order for political stability in Egypt and protecting human rights in the transition period, "restoration of Egypt's democracy" by giving voices to all segments of society including the Morsi supporters, the difficulty of transition to democracy and the primacy of the will of the people, as well as "the longstanding partnership between the US and Egypt based on shared interests" (obamawhitehouse.archives.gov, 12.03.2019). As it can be seen in the Obama's expressions, the US preferred to accept the de facto rule of the Egyptian military. Instead of challenging the overthrow of an elected President by a military intervention, the US interpreted the situation as a result of a popular movement which represents the will of the Egyptian people. Furthermore, Obama underlines the fact that the US remains neutral by taking neither side in the domestic struggle of Egypt. Apart from that, Obama repeatedly addressed their commitment to the democratic principles and returning to democratic processes even after the military intervention. Actually, it was not so surprising depending on the traditional US discourse based on democracy promotion in the region. However, Obama claims that 
these democratic processes do not depend on particular individuals or political parties so neutrality of the US indicates their commitment to the principles rather than actors. On the other hand, Shadi Hamid (2015) argues that "the notion of neutrality for a powerful country like the US is illusory". According to him, "doing nothing or 'doing no harm' means maintaining or reverting to the status quo, which is never neutral". I think, this interpretation is of crucial importance because of the fact that if an actor has enough capacity to have an influence on the decisions and policies of other actors, its quietness or abstention refers to a position as well. When the great role of the US not only for the region in general but also for Egypt and Egyptian military is taken into account, it can be easily claimed that even its neutrality has certain implications and carries potential to change the balance of power in the country.

Obama sent other messages during the popular protests just before and after the military intervention. He implicitly supported the demands of popular protests against him by urging Morsi to consider "other options". Obama mentioned that "Democracy is not just about elections. It's also about the way of working with an opposition and treating minority groups and dissenting voices" (Roberts, 2013). Moreover, the spokesman of the State Department called Morsi to take some steps to be responsive to the Egyptian people. It can be said that Obama and other US representatives considered the demands of the Egyptian people protesting Morsi Presidency as legitimate and they found the policies or precautions of Morsi towards these demands unsatisfactory. In that sense, they attribute at least some part of the responsibility to the Morsi administration. It does not mean that these expressions justify the military intervention but they are still meaningful for a country in which there was political chaos in that period. A similar reaction can be seen in David Cameron's remarks by referring to not achieving compromises in the last year in Egypt (Alexander, 2013).

Looking at the other side of the coin, calling the event as a "coup" had different meanings for the US due to its legal consequences. According to the US law, the US had to cut off financial assistance to Egypt in case of determining it as a military coup (Baker, 2013). Therefore, it was worth to 1.5 billion US dollars both for the US government and, more importantly, for Egypt. In other words, there were concrete results and sanctions of naming of the military intervention in the Egyptian case so the US representatives took their steps cautiously and never used the word "coup" in their expressions. It is necessary to consider the importance of US-Egyptian alliance in that context. Egypt has long been a crucial regional ally for the US and the US government has always aimed to keep Egypt's longstanding peace agreement with Israel. It was vital for the US interests in the region; therefore, the US wanted to keep good relations with Egypt by sending financial and military aid to it. Most commentators emphasized that although the US officials were aware of the fact that it was obviously a military coup, they did not want to suspend the annual grant to the Egyptian military due to its history as a US ally and its strategic importance for the peace with Israel (washingtonpost.com, 10.03.2020). "A complete cutoff of aid would not only lead to increase the risks in Egypt and the Middle East but also set back important foreign policy goals and damage the US reputation as a reliable ally" (Phillips, 2013). "In the Egyptian context, the military's role as the sole interlocutor between Egypt and the United States contributed to the U.S. decision not to name overthrow of Morsi a coup" (Aziz, 2013). By this way, the US could avoid weakening the Egyptian military which was one of the most stable institutions in the country (Reuters, 2013). Nicolas Bouchet (2016) interprets the dilemma of the US administration about the hard choices between ideals and interests, and underlines the fact that the failure of the US decision not to call it a coup led to decrease its credibility in terms of democracy promotion in the regional and global sense. Of course, it was not peculiar to the last military intervention in Egypt. On the contrary, it was a general problem of the US foreign policy towards the Middle East. For the Egyptian case, Glenn Greenwald (2014) considers the US policy as "after feigning love for Egyptian democracy, US back to openly supporting tyranny". As a result, the US policy and discourse reflected the primacy of regional stability and maintenance of alliances instead of unconditional support for principles and democracy promotion.

\section{Results and recommendations}

When the military intervention happened in Egypt, the position or reaction of the US representatives were critical due to its traditional role in the political and military affairs of the country. President Obama preferred to express that they were "deeply concerned" with the events in Egypt but he did not choose one side and explained their position as a kind of neutrality. Obviously, the quietness or so-called 
"neutrality" of a hegemonic power has certain meanings and implications. It was unimaginable for the Egyptian military to take the rule in their hands without, implicit or explicit, consent of the US due to dependence of the armed forces to the US support. The declaration of the US about taking neither side paved the way for the military and it did not miss that opportunity coming out of the domestic context and the support of external actors. In terms of the historical record of the US discourse and foreign policy towards the Middle East, this policy of the US was not so surprising. Though "democracy promotion" has long taken part in the US discourse, the US administrations preferred to pursue their interests when they were in conflict with the ideals. In other words, national interests of the US outweighed the ideals such as democracy promotion or human rights all the time. Good relations of the US leaders with the authoritarian regimes of the Middle East can be considered as examples of the US priorities in the region. When the Arab Uprisings emerged and spread throughout the region, the US adopted different policies in different countries. Obama was among the leaders who called Mubarak to step down but it was not so easy to consider that policy as a kind of unconditional support for democracy. The US preferred to have a cautious policy towards the Arab Uprisings and decided to implement pragmatic policies in the region. In the Egyptian case, it was almost certain that Mubarak would not remain in power as a result of mass protests so it was unrealistic for the US to support Mubarak regime against the Egyptian people. On the contrary, it was beneficial for the US to legitimize its rhetoric and to reduce anti-American feelings in the region. However, the political context in Egypt changed dramatically in a short period of time and mass protests were organized against Morsi administration in the end. It was a protest of large groups of people against the first democratically elected leader of Egypt. Thus, it created another dilemma for the external actors. It was actually hard to keep Morsi in power in the name of democracy but it would certainly mean supporting democracy in any case but it was not the way the US and other external powers followed in the previous periods. The rule of Egyptian military was more compatible with the US interests compared to domination of the Muslim Brotherhood in Egyptian politics. Once again, the US preferred their interests instead of norms and ideals.

Discourse analysis is a method based on different usages and meanings of language. In the case of Egypt, Obama's expressions best exemplify referring some policies without directly mentioning them. For instance, Obama said "The United States does not support particular individuals or political parties, but we are committed to the democratic process and respect for the rule of law". By saying that, he refrained from taking responsibility of certain actors. Instead, he underlines the primacy of democratic principles and processes. It can be interpreted as the recognition of the US administration in the changes of the ruling actors. Put differently, Obama claims that the same principles can be achieved by different actors so he calls the Egyptian military to return to democratic path urgently. Furthermore, Obama defines a monitoring position for the US instead of challenging the military rule. It implies that the transformation in the domestic affairs would continue and the US would just observe the events in that process. The "neutrality" of the US can be seen as a tacit consent for the revisionist groups in that context. Apart from that, Obama presents a roadmap by reminding the democratic principles for the next period. He underlines the need for inclusive government respecting the rights and demands of all groups. In my opinion, this emphasis on "inclusiveness" refers to the opposition against Morsi. In other words, Obama most probably meant that Morsi could not achieve establishing an inclusive rule in his period; thus, it led to current political crisis in Egypt and it was necessary to have an all-encompassing approach for the stability in the country. In the end, Obama puts that crisis as a normal difficulty in the transition to democracy and addressed the longstanding relationship between the US and Egypt based on shared interests and values. It can be regarded as an expression of the importance of alliance with Egypt for the US interests in the region.

In terms of financial aid to Egypt, it was important not to call the military intervention as a coup but it would not change the US policies towards Egypt dramatically. There is still a huge gap between democracy rhetoric of the US and its policies based on interests. Therefore, the matter of financial aid was not so decisive for the US policies. It can be considered as a kind of tactical maneuver rather than a strategic decision. The decisions or policies of a hegemonic power cannot be enforced or imposed by other actors so criticisms towards the US can only affect the credibility or reliability of the US as an ally. This kind of tactical maneuvers might seem crucial in the short term but strategies and visions towards the region will certainly outweigh in the long-term. The great powers always keep in mind that 
fact. They always aim to control the area and have different alternatives rather than investing all their assets to one side. The US influence on Egypt will remain powerful despite some changes in the actors and tools. The US discourse on the last military intervention in Egypt can only be an example of the US strategy.

Compared to the EU foreign policy towards the Arab Uprisings, the EU followed a similar pattern about the last military intervention in Egypt. Since the US has national interests and a central authority, decision-making mechanisms, perceptions of threat and interests differ from the EU which is a supranational body. It is not possible to talk about a common foreign policy for the EU member states so it will be better if we take into account the existence of different actors having clashing interests within the EU. Therefore, it is not so easy for European states to have a grand strategy and direct influence in other parts of the world. While the US can impose order or at least affect the regional balance of power in the Middle East, the EU and only some leading European states have limited influence in other regions. It is still open to question to what extent the EU is an effective global power. On the other hand, the US keeps its supremacy in the global power struggle despite losing some of its hegemony throughout the world. The decisiveness of both, the EU and the US, can be seen in the last military intervention in Egypt. They both have a gap between rhetoric and practice but the policies of the US have always had much more concrete results as can be observed during the Arab Uprisings once again. In terms of the normative aspect of the EU, the EU policies during the Arab Uprisings constituted another missed opportunity for turning into an effective normative actor. While there was consistency in the EU discourse in terms of emphasizing the EU norms and principles, it could not contribute to concrete results on the ground due to lack of supporting EU policies and common will among the member states.

\section{References}

Alexander, H. (2013, July 4). World reaction to Egypt coup. The Telegraph. Retrieved on 21 May 2018, from

http://www.telegraph.co.uk/news/worldnews/africaandindianocean/egypt/10159658/Worldreaction-to-Egypt-coup.html

Aziz, S. (2013, July 31). US foreign aid and Morsi's ouster. Middle East Institute. Retrieved on 12 February 2020, from http://www.mei.edu/content/us-foreign-aid-and-morsis-ouster

Baker, P. (2013, July 4). A coup? Or something else? \$1.5 billion in US aid is on the line. The New York Times. Retrieved on 12 February 2020, from http://www.nytimes.com/2013/07/05/world/middleeast/egypts-arrests-of-islamists-pose-test-tous-over-military-aid.html

Bax, S. (2011). Discourse and genre: Analysing language in context. London: Palgrave Macmillan.

Bouchet, N. (2016, September 6). Long game, hard choices: The Obama administration and democracy in Egypt. E-International Relations. Retrieved on 18 April 2019, from http://www.eir.info/2016/09/06/long-game-hard-choices-the-obama-administration-and-democracy-in-egypt/

Catherine Ashton EU High Representative for Foreign Affairs and Security Policy and Vice President of the European Commission remarks on Egypt and Tunisia. (2011, February 2). Retrieved on 10 May 2020, from https://ec.europa.eu/commission/presscorner/detail/en/SPEECH_11_66.

Cole, J. R. I. (2013). US Middle East policy in Obama's second term. The Emirates Center for Strategic Studies and Research, 99, 1-21.

Collins, V. E. \& Rothe, D. L. (2012). United States support for global social justice? Foreign intervention and Realpolitik in Egypt's Arab Spring. Social Justice, 39(4), 1-20.

Cox, M. (2013). Fighting for freedom: Promoting democracy the American Way. Harvard International Review, 34(4), 36-39.

Garcia, D. \& Gluesing, J. C. (2013). Qualitative research methods in international organizational change research. Journal of Organizational Change Management, 26(2), 423-444.

Gee, J. P. (1999). An introduction to discourse analysis. London: Routledge.

Ghilés, F. (2012). A new deal for Arab people. Insight Turkey, 14(1), 13-27.

Greenwald, G. (2014, October 2). After feigning love for Egyptian democracy, US back to openly supporting tyranny. The Intercept. Retrieved on 15 January 2020, from 
https://theintercept.com/2014/10/02/feigned-american-support-egyptian-democracy-lastedroughly-six-weeks/

Hamid, S. (2015, October 9). Islamism, the Arab Spring, and the failure of America's do-nothing policy in the Middle East. The Atlantic. Retrieved on 10 August 2019, from https://www.theatlantic.com/international/archive/2015/10/middle-east-egypt-us-policy/409537/

Johnstone, B. (2002). Discourse analysis. Oxford: Blackwell Publishing.

Karacasulu, N. \& Karakır, I. A. (2014). EU-Turkey relations in the context of the Middle East after the Arab Spring. Insight Turkey, 16(4), 201-219.

Karakir, I. A. (2014). Limits of EU democracy promotion in the Arab Middle East: The cases of Egypt and Morocco. Uluslararası Hukuk ve Politika, 10(38), 33-67.

Kivimaki, T. (2013). The United States and the Arab Spring. Journal of Human Security, 9(1), 15-26.

Metawe, M. (2013). How and why the West reacted to the Arab Spring: An Arab perspective. Insight Turkey, 15(3), 141-155.

Miller, Z. J. (2013, July 3). Apparent Egyptian military coup puts Obama in bind on military aid. Time. Retrieved on 12 February 2020, from http://swampland.time.com/2013/07/03/apparent-egyptianmilitary-coup-puts-obama-in-bind-on-military-aid/

Monshipouri, M. \& Assareh, A. (2011). The new Middle East and the United States: What to expect after the Uprisings? Insight Turkey, 13(3), 121-138.

Nau, H. R. (2010, April 1). Obama's foreign policy. Hoover Institution, 160, $27-47$.

Nuruzzaman, M. (2015). President Obama's Middle East policy, 2009-2013. Insight Turkey, 17(1), 171190.

Perez de las Heras, B. (2015). EU and US external policies on human rights and democracy promotion: Assessing political conditionality in Transatlantic Partnership. Romanian Journal of European Affairs, 15(2), 80-96.

Phillips, J. (2013, August 23). Egypt's coup requires a cautious US response. The Heritage Foundation. Retrieved on 15 January 2020, from http://www.heritage.org/middle-east/report/egypts-couprequires-cautious-us-response

Pierce, A. R. (2014). US "partnership" with the Egyptian Muslim Brotherhood and its effect on civil society and human rights. Society, 51(1), 68-86.

Pinto, M. C. (2012). Mapping the Obama administration's response to the Arab Spring. Revista Brasileira de Politica Internacional, 55(2), 109-130.

Ramadan, T. (2012). The future of political Islam in the Arab World. The Emirates Center for Strategic Studies and Research, 93, 1-25.

Ratka, E. (2012). Germany and the Arab Spring-foreign policy between new activism and old habits. German Politics and Society, 30(2), 59-74.

Reuters, T. (2013, July 4). Why the US doesn't call Egypt military's ouster of Morsi a coup. CBC News. Retrieved on 14 February 2020, from http://www.cbc.ca/news/world/why-the-u-s-doesn-t-callegypt-military-s-ouster-of-morsi-a-coup-1.1347857

Roberts, D. (2013, July 3). US in bind over Egypt after supporting Morsi but encouraging protestors. The Guardian. Retrieved on 8 July 2019, from https://www.theguardian.com/world/2013/jul/03/egypt-obama-us-mohamed-morsi-crisis

Rouet, G. (2014). Turbulences, European Neighbourhood Policy and European identity. Politické Vedy, 17(2), 9-27.

Schumacher, T. (2011). The EU and the Arab Spring: Between spectatorship and actorness. Insight Turkey, 13(3), 107-119.

Sharp, J. M. (2014). Egypt: Background and US relations. Current Politics and Economics of Africa, 7(1), 47-94.

The EU's response to the "Arab Spring". (16 December 2011). Retrieved on 9 June 2020, from https://ec.europa.eu/commission/presscorner/detail/en/MEMO_11_918

Turner, J. (2012). Untangling Islamism from Jihadism: Opportunities for Islam and the West after the Arab Spring. Arab Studies Quarterly, 34(3), 173-188.

US must suspend aid after Egypt's coup. (4 July 2013). The Washington Post. Retrieved on 10 March 2020, from https://www.washingtonpost.com/opinions/us-must-suspend-aid-after-egypts- 
coup/2013/07/04/cd53f248-e4a8-11e2-a11e-

c2ea876a8f30_story.html?utm_term=.300397072f76

White House. (2009, June 4). Remarks by the President at Cairo University. Retrieved on 12 March 2019, from https://obamawhitehouse.archives.gov/the-pressoffice/remarks-president-cairouniversity-6-04-09

White House. (2011, January 14). Statement by the President on events in Tunisia. Retrieved 12 March 2019, from https://obamawhitehouse.archives.gov/the-press-office/2011/01/14/statementpresident-events-tunisia

White House. (2011, February 10). Statement by President Barack Obama on Egypt. Retrieved 12 March 2019, from https://obamawhitehouse.archives.gov/the-press-office/2011/02/10/statementpresident-barack-obama-egypt

White House. (2011, February 11). Remarks by the President on Egypt. Retrieved 12 March 2019, from https://obamawhitehouse.archives.gov/the-press-office/2011/02/11/remarks-president-egypt

White House. (2013, July 3). Statement by President Barack Obama on Egypt. Retrieved on 12 March 2019, from https://obamawhitehouse.archives.gov/the-press-office/2013/07/03/statementpresident-barack-obama-egypt

Wollack, K. (2010). Assisting democracy abroad: American values, American interests. Harvard International Review, 32(3), 20-25.

Wood, L. A. \& Kroger, R. O. (2000). Doing discourse analysis. Thousand Oaks: Sage Publications.

World leaders voice concern, optimism over Egyptian coup. (2013, July 4). Deutsche Welle. Retrieved on 21 February 2019, from https://www.dw.com/en/world-leaders-voice-concern-optimismover-egyptian-coup/a-16928311

Wouters, J. \& Duquet, S. (2013). The Arab Uprisings and the European Union: In search of a comprehensive strategy. Yearbook of European Law, 32(1), 230-265.

\section{Ethical approval}

This study is among the studies that do not require ethics committee approval due to the fact that it is based on open access or secondary sources.

\section{Conflict of interest}

There is no potential conflict of interest in this study. 